Meta

Journal des traducteurs

Translators' Journal

\title{
On the Hong Kong Chinese Subtitling of English Swearwords
}

\section{Chapman Chen}

Volume 49, numéro 1, avril 2004

Traduction audiovisuelle

Audiovisual Translation

URI : https://id.erudit.org/iderudit/009029ar

DOI : https://doi.org/10.7202/009029ar

Aller au sommaire du numéro

Éditeur(s)

Les Presses de l'Université de Montréal

ISSN

0026-0452 (imprimé)

1492-1421 (numérique)

Découvrir la revue

Citer cet article

Chen, C. (2004). On the Hong Kong Chinese Subtitling of English Swearwords. Meta, 49(1), 135-147. https://doi.org/10.7202/009029ar
Résumé de l'article

Nous nous efforcerons dans les pages qui suivent de montrer comment les jurons de l'anglo-américain sont sous-traduits à Hong Kong. Nous tenterons d'expliquer en termes d'autorité sociale, de stratégies illocutionnaires et sociolinguistiques pourquoi ces jurons ne sont pas traduits correctement, et nous préconiserons pour leur sous-titrage chinois l'adoption d'équivalents cantonais plus dynamiques. À cet effet nous soulignerons le besoin de prendre en compte les différences linguistiques, psycho sexuelles et religieuses entre les cultures chinoise et occidentales dans la traduction des jurons américains. 


\title{
On the Hong Kong Chinese Subtitling of English Swearwords
}

\author{
CHAPMAN CHEN \\ Hong Kong Polytechnic University, Hung Hom, Hong Kong \\ tcmchen@polyu.edu.hk
}

\begin{abstract}
RÉSUMÉ
Nous nous efforcerons dans les pages qui suivent de montrer comment les jurons de l'anglo-américain sont sous-traduits à Hong Kong. Nous tenterons d'expliquer en termes d'autorité sociale, de stratégies illocutionnaires et sociolinguistiques pourquoi ces jurons ne sont pas traduits correctement, et nous préconiserons pour leur soustitrage chinois l'adoption d'équivalents cantonais plus dynamiques. À cet effet nous soulignerons le besoin de prendre en compte les différences linguistiques, psycho sexuelles et religieuses entre les cultures chinoise et occidentales dans la traduction des jurons américains.
\end{abstract}

\section{ABSTRACT}

The objectives of this article are to illustrate how American English swearwords are under-translated in Hong Kong; to explain why English swearwords are inadequately translated in Hong Kong in terms of patronage, illocutionary strategies, and socio-linguistics; to advocate the adoption of Cantonese dynamic equivalents in subtitling English-speaking movies, in particular, American swearwords; to suggest Cantonese dynamic equivalents for American swearwords in Chinese subtitling; and to emphasize the need to pay attention to linguistic, psychosexual, and religious differences between Chinese and Western cultures when subtitling American swearwords.

\section{MOTS-CLÉS/KEYWORDS}

Cantonese subtitling, censorship, comparative cultural studies, English swearwords, films

\section{Introduction}

Movies are big business in Hong Kong. All major Hollywood movies are shown in Hong Kong theatres, frequently at the same time as in North America. According to law, all English-speaking movies shown in Hong Kong must have Chinese ${ }^{1}$ subtitles. Moreover, subtitled VCDs and DVDs of most of the English-speaking movies shown in Hong Kong theatres become available on the market one to two months after they are shown. Subtitling has a long history in Hong Kong. It is part of the curriculum of both the B.A. and M.A. in Translation programs offered by the Translation Department of the Chinese University of Hong Kong.

The aims of this paper are to illustrate how under-translated American English swearwords are in Hong Kong Chinese subtitles of English-speaking movies and to explain the causes of this phenomenon.

A table is drawn to compare original English swearwords with their renderings in subtitles in VCDs distributed in Hong Kong, with the writer's Cantonese suggestions (see appendix). 


\section{How are American English swearwords under-translated in Hong Kong Chinese subtitles?}

Usually, in VCDs produced in Hong Kong, English swearwords either remain untranslated, or they are subtitled over-formally, or into Putonghua.

a) Un-translation

Look at example 3 of "mother-fucker" in the table. In this example, the speaker is trying to rob a restaurant, but the swearwords, "fuckin," " pricks," and "mother-fuckers" are all untranslated in the VCD subtitled version. The resulting Chinese version is "uninteresting and stripped of emotion," to borrow Fong's words (2001: 6).

b) Over-formal Translation

In example 3 of "cock/dick/prick," the speaker is ridiculing a mentally retarded man such that the utterance is supposed to be very colloquial and naughty. In the VCD version, however, "dick" is subtitled as the formal term joeng-geoi [penis].

Consider the column "cunt" in the table. In Silence of the Lambs, when the heroine played by Jodie Foster goes to visit Dr. Lecter (Anthony Hopkins) in his cell in an asylum, she has to walk past a series of other grim cells. One of the nasty, insane inhabitants swears at her, "I can smell your cunt," splashing his semen onto her. In the VCD version, the swearword is subtitled as jam-bou [genitalia], which is a very formal term, while the dynamic equivalent in Cantonese is probably "cau-hai [stinking cunt]," the low register of which closely matches the original tone and situation.

c) Rendition into Putonghua

A lot of VCD subtitled versions render English swearwords into Putonghua swearwords, ignoring the fact that most of the Hong Kong audience's mother tongue is Cantonese (see section 4). In example one of "fuck (verb)," the killer in the farcical movie shows a girl that he has already subdued her friend, who is crying to the girl for help. The girl, in order to save herself, tells the killer that the poor guy is not her friend, and that she has only fucked him a couple of times. The vulgar word, "fuck," is subtitled as cou [drill], which is the Putonghua swearword for "fuck," instead of "diu," the Cantonese equivalent.

In American Psycho, when the anti-hero reprimands his fiancée that she is dating an "asshole," the swearword is subtitled in the VCD version as wan-daan [wretch], which is a Putonghua expression, rather than the conventional Cantonese rendition, "si-fat-gwai [anal ghost]" (see below 5b).

d) Use of Euphemisms

Even in Category III movies (se 3a), Hong Kong subtitlers dare not render hard-core English swearwords into their hard-core Cantonese equivalents. The farthest they will go is to render them into semi-homonymous euphemisms of hard-core Cantonese swearwords. For instance, "fuck (noun)" is subtitled as “jiu [freak]," which rhymes with "diu [fuck].”

Look at the "fuck (noun)" column in the table. In Relax... It's Just Sex, when a lady discovers her boyfriend's plane ticket, indicating that he is going to leave her secretly, she confronts him angrily with the question, "Exactly, what the fuck is this?" The swearword is subtitled as "jiu [freak]," which rhymes with "diu [fuck]." But the dynamic equivalent in Cantonese is probably the hardcore "lan [dick]." 


\section{Why are English swearwords under-translated?}

a) The Hong Kong system of film censorship divides films shown in Hong Kong cinemas into three categories ${ }^{2}$ :

I. "Approved for exhibition to persons of any age."

IIa. "Approved for exhibition to persons of any age" but subject to displaying the symbol "Not suitable for Children";

IIb. "Approved for exhibition to persons of any age" but subject to displaying the symbol "Not suitable for young persons and children";

III. "Approved for exhibition only to persons who have attained the age of 18 years."

According to Fong (2001: 8), a few film distributors he interviewed maintained that the box office was their greatest concern. If only one hard-core Cantonese swearword is discovered by the authorities in the dialogue or subtitles, the movie will automatically be rated Category III, which is restricted to persons of 18 years or above, and teenagers, who account for a major proportion of the movie-going public, will not be able to enter the cinema to watch the movie. "Subtitlers and their employers, the distributors, have to be particularly careful with subtitles in order not to suffer any loss in profit."

Nonetheless, hard-core English vulgarisms are often not rendered into their Cantonese equivalents even in Category III movies. So there must be some other factor at work than just censorship and financial profit.

b) Another factor causing the under-translation of English vulgarisms in Hong Kong subtitles would be how linguistic devices are made use of in our time. According to Ivarsson and Carroll (1998: 83), swearwords seem more unacceptable when written, in particular, in subtitles, than when spoken, probably because written words seem more concrete and hard to deny than oral utterances. As pointed out by Can (1999: 4), this applies particularly well to Hong Kong. The need to avoid or to tone down written swearwords is therefore imposed on subtitlers by the dominant "language poetics" of our day.

c) Yet another factor must be socio-linguistic. According to Bauer (1988: 285), the Hong Kong Chinese's attitude towards Cantonese is remarkably ambivalent: "On the one hand, many Hong Kong Cantonese-speakers openly acknowledge that Putonghua has higher prestige than Cantonese whose regional status they readily recognize. But on the other hand, they are still proud of being Hong Kong Cantonese-speakers." Moreover, "overt disapproval of written Cantonese is offset by covert tolerance and even acceptance, since one finds it occurring in so many different places and with such a high frequency in relation to standard Chinese" (id.: 287).

Under such circumstances, as put by Fong, "some people are still not used to seeing Cantonese in written form [including subtitles], even though its use in newspapers and other print media is becoming more widespread" (2001:5).

\section{Why should Cantonese equivalents be used to subtitle American English swearwords?}

The use of Cantonese equivalents is better for subtitling English swearwords in movies because they convey the original spirit most effectively and arouse the greatest 
empathy on the part of the Hong Kong audience, who are mostly native speakers of Cantonese.

Lung (1998: 4) has pointed out that sexually suggestive elements are often omitted or mistranslated in English-Chinese subtitling, as a result of which impact is lost in their rhetorical uses.

From the point of view of Nornes (1999), only by fully utilizing the power of the target language are we able to "intensify the interaction between the reader (audience) and the foreign," which, is one of the most significant functions of subtitling, and therefore, one of the greatest joys of going to the cinema.

According to a survey done by Lo Wai Yan on the attitude of the Hong Kong audience towards using Cantonese in subtitles, more than $50 \%$ of the 413 respondents consider that Cantonese, compared to standard Chinese, is better able to render the spirit of the original English vulgar expressions (2001: 126). Additionally, movie fans writing in Internet chat rooms agree that Cantonese subtitles are "direct," "familiar," and since they can catch the original spirit, they make the audience feel more engaged and the movie-watching experience more pleasurable (id.: 138-39).

Finally, it does not constitute a Category III rating when f-words are spoken and heard in English, only when they are written and seen in Chinese. In fact, according to Can Zitman, a veteran Hong Kong dramatist, although swearwords can be heard everywhere in everyday life, they appear much less frequently in texts of Chinese culture which stresses the importance of the cleanliness of written language. However, swearwords can readily be seen in Western plays and scripts. Can's book, which is a collection of short plays, therefore includes a certain amount of swearwords as a tool for accurately describing a particular class or a particular type of people (1999: 4). The under-translation of English swear words is a phenomenon which obviously demonstrates linguistic prejudice and inequality, and Hong Kong people should struggle for the right to see the original features of English swearwords revived in the subtitles.

\section{Linguistic, psychosexual, and religious factors}

When subtitling English swearwords into their Cantonese equivalents, one must pay close attention to the linguistic, psychosexual, and religious differences between American and Chinese languages and cultures.

\section{a) Linguistic Factors}

American English swearwords, like "fucking" and "goddamn," when used as adjectives are at times placed before the noun while their Chinese adjectival equivalents are usually placed immediately after the verb. In example 2 of "fucking," the English adjectival swearword is placed before the English noun-object, "head," whereas in Chinese, the Cantonese equivalent for fucking - "lan [prick/dick]" - works better when shifted to the position immediately after the verb, "zaam [chop]."

b) Psychosexual Factors

The historian, Syun Lunggei (1992: 184-85), points out that the Chinese people seem to be fixated at the oral and the anal stages. Sigmund Freud (1973-86) divides the psychosexual development of children into three stages - oral, anal, and phallic. In the oral stage, the infant's main interest is sucking at the maternal breast. In the anal 
stage, anal, urethral and muscular sadisms predominate and the child likes playing with its own feces as it is its own creation. In the phallic stage, roughly between the ages of two and five, the pre-eminence of the phallus is set up such that boys desire their mother as a sexual object and hate their father as a rival. Freud called this the Oedipus complex (direct), and he believed that it was irrational, destructive, uncontrollable, and universal (1973-86: v.15, pp. 142-43, 385, 423-24).

i) Chinese orality and "mother-fucker"

According to Syun Lunggei, the Chinese mother spoils her infant by feeding it at any time (especially if it is a boy) and simply inserting food into its mouth whenever it cries. Consequently, the Chinese people, more than any other people in the world, have always been strongly attached to and immaturely dependent upon the mother's breast (1992: 184-85). In fact, Syun calls the Chinese people an unweaned race (1995: $119,150,160-61,185)$.

By contrast, in the West, it is generally believed that the son must run away from the mother in order to be a real man, and that people who remain attached to their mother in adulthood are either homosexuals or psychotics like the Oedipal hero of Hitchcock's classic movie, Psycho, or the transvestite-psychotic in Silence of the Lambs who skins girls (cf. Syun Lunggei [1995: 250-368, passim]). Now you can see why the most suitable dynamic equivalent of "mother-fucker" is "diu-nei lou-mou [fuck your mother]," rather than "diu lou-mou ge jan [a person who fucks his/her own mother]." For example, in Pulp Fiction, immediately before the rude professional killer, Jules, is going to kill a young man, he teases him and asks him threateningly, "Englishmother-fucker-can-you-speak-it?" In the VCD version, the swearword is translated as the Beijing swearword, waai-zung [bad seed], while the writer of this paper thinks that a Cantonese gangster in this situation will almost certainly say, "diu-nei lou-mou [fuck your mother]." Nonetheless, when "mother-fucker" must be translated as a noun but not a verb phrase, we may render it into non-sexual Cantonese swearwords, which can be used as nouns, like "ham-gaa-caan [whole-family-uprooted]," "pukgaai [drop-dead-in-the-street]," and "laan-taan [paralytic]." For instance, in Dogma, when the foul-mouthed Jay hears some strange voice in a restaurant, he asks, "Now who's this mother-fucker?" and his companion Rufus answers, "This is the Voice of God - show some respect." In the VCD version, the swearword is appropriately subtitled as "puk-gaai [drop-dead-in-the-street]."

ii) Chinese anality

Most Mainland Chinese appear to be fixated at the anal stage. They will spit, fart, pick their nose, and litter in public. And toilets in Mainland China are notoriously filthy, compared with those in the West. This may be due to the fact that the toilet training of Mainland Chinese tends to be lax. Mainland Chinese children, especially in rural areas, usually wear open-seat split pants so that they may urinate and defecate whenever and wherever it suits them.

As a result of their anality, the Chinese would not consider words like "si [shit]" and "si-fat-gwai [ass ghost/asshole] very offensive. But "sik-si [eat shit]" as a rendition of "shit" is better than non-translation after all. Or maybe, "ding [butt]," which has a little sexual connotation, can somehow express the resentfulness of "shit." For example, in Scary Movie, before the psychotic killer begins to get one of his victims, he phones her up and asks her to guess where he is. The victim spots his knife when he is hiding 
himself behind a sofa, and tells him his position. The killer then exclaims, "Oh, shit! How come you know I'm behind the sofa!" Here, "shit" remains untranslated in the VCD version, while the writer of this paper thinks that "ding" would be a very appropriate rendition.

And "si-fat gwai" seems to have been integrated into the Hong Kong Cantonese language so that we may use it to translate "asshole" although the Cantonese version is not extremely offensive. For an example, see III C, above.

c) Religious Factor

Christianity has dominated the West for two thousand years while it did not enter China on a massive scale until the end of the nineteenth century. Even now, only about ten percent of the people in Hong Kong are baptized and far less than one percent of Mainland Chinese are Christians. This cultural difference is clearly reflected in the way Westerners and the Chinese swear. Let's take two examples.

When swearing, Westerners like to say, "Goddamn," either as adjective or as verb, while no Chinese, not even Christians, would say anything like "soeng-dai zo-zau [God damn]," when pouring abuses on others. For example, when the anti-hero in American Psycho comes across a street-sleeper, he urges him, "Get a Goddamn job," which is subtitled in the VCD as "Heoi zau jat-fan gung maa, maa-dik [Go find a job, mother's]. The euphemistic Putonghua swearword, "maa-dik," is again very weak to the Cantonese. And "Goddamn" here, in the writer's opinion, would be better subtitled as the verb phrase, "diunei [fuck you]" - which is what a native speaker of Cantonese would say in this kind of situation - and moved to the end of the utterance.

According to orthodox interpretation of the Bible, anal intercourse between males is a most serious sin. Consequently, homosexuality had been criminalized and homosexuals severely persecuted for more than fifteen hundred years in the West until the second half of last century. In the American English language, there are a lot of swearwords involving homosexuality, e.g., "faggot," "bugger," "asshole," "sodomite," to name only a few. In China, however, homosexuality has never been criminalized. There was no prejudice against it in China until Western colonialism began to instill homophobia in the minds of the Chinese people near the end of the Qing Dynasty (cf. Zau Waasaan and Ziu Manzung 1995:142-146). Correspondingly, in Hong Kong, the only swearwords involving homosexuality are "sei gei-lou [dead gay guy]," "kai-dai [feminine younger brother]" and "si-fat gwai [ass-ghost/ asshole]. Needless to say, "gei [gay]" is an English loan word, and, as aforementioned, "si-fat gwai" is an almost literal translation of "asshole." Only "kai-dai," which has an almost humorous tint, is more or less purely of Chinese origin. Anyway, their impact on the Chinese listener is less than that of English homosexual swearwords on Westerners. For example, at one point in American Beauty the homophobic father says to his son, "I'd rather you were dead than be a fucking faggot." This utterance is so full of sexual orientation discrimination that translating "a fucking faggot" as "gei-lou" is definitely not enough. We must add "lan [prick]," the Cantonese equivalent for "fucking," to the position immediately after the verb, "sei [die]," in the line, in order to convey the vulgarity and malice of the original. 


\section{Conclusion}

In conclusion, in Hong Kong Chinese subtitles, American English swearwords are usually under-translated - either untranslated, translated over-formally, or rendered into Putonghua-not the mother-tongue of the majority of the Hong Kong audienceor rendered into euphemisms. In order to help the audience become more involved in the film-watching experience, English swearwords should be subtitled with their Cantonese dynamic equivalents, as Cantonese is the mother-tongue of most Hong Kong people. Furthermore, when subtitling English swearwords, attention must be paid to certain subtle but important linguistic, psychosexual, and religious differences between Western and Chinese cultures.

\section{NOTES}

1. All the Chinese characters in this paper are transliterated according to the Cantonese Romanization Scheme of The Linguistic Society of Hong Kong (Hoenggong Jyujinhok Hokwui 1997: xxi-xxii).

2. Special considerations are given for "artistic, education, literary or scientific merit" in relation to "the intended exhibition of the film, the circumstances of such exhibition" (for instance, film festivals).

\section{REFERENCES}

\section{Books and Articles}

Bauer, R. S. (1997): "Hong Kong Cantonese and the Road Ahead," David C. S. Li, A. L., and W. K. Tsang (eds.) (2000): Language and Education in Postcolonial Hong Kong, Hong Kong, Linguistic Society of Hong Kong, pp. 35-58.

Bauer, R. S. (1988): "Written Cantonese of Hong Kong," Cahiers de Linguistique Asie Orientale XVII. 2, pp. 245-293.

Bolton, K. and C. Hutton (1977): "Bad Boys and Bad Language," Grant Evans and Maria Tam (1977), pp. 299-332.

Can, Z. (1999): Preface, Sangming Batnang Singsau dik Gung - Sapfan Hoenggong Dukbaak [The Unbearable Work in Life - Ten Hong Kong Monologues], Hong Kong, Wailaamtin, pp. 2-9.

Chen, C. (2001): "A Critical Evaluation of a Chinese Subtitled Version of Hitchcock's Spellbound," Paper given at the International Conference on Dubbing and Subtitling in a World Context (19.10.2001), Translation Department, Chinese University of Hong Kong, Hong Kong.

DAAI, F., trans. (1999): Ceothau Singzoeng Hok Jingjyu (English as a Fucking Language), by Sterling Johnson, Taipei, Ziktin.

Evans, G. and M. Tam (eds.) (1997): Hong Kong: The Anthropology of a Chinese Metropolis, Surrey, Curzon Press.

Fong, G.. C. F. (2001): "The Two Worlds of Subtitling: The Case of Vulgarisms and Sexually Oriented Language," International Conference on Dubbing and Subtitling in a World Context (19.10.2001), Translation Department, Chinese University of Hong Kong, Hong Kong.

Freud, S. (1973-86): Pelican Freud Library, trans. James Strachey, ed. Angela Richards, 15 vols., Harmondsworth, Penguin.

Ivarsson, J. and M. Carroll (1998): Subtitling, Sweden, Simrishamn.

LeI, W.(1999): Dinjing Feisoeng Leijyu [Extraordinary Slang in Movies], Hong Kong, Manlam SE.

Lo, W. Y. (2001): "Film Translation in Hong Kong: Cantonese Subtitles and Transparency." M. Phil. thesis, Chinese University of Hong Kong, Hong Kong.

Lung, R. (1998): "On Mistranslating Sexually Suggestive Elements in English - Chinese Screen Subtitling," Babel 44, 2, pp. 97-109.

Nornes, A. M. (1999): “For an Abusive Subtitling," Film Quarterly Spring 1999, pp.35-45.

SHU, K. (2001): "Translating Subtitles for the Hong Kong Audience - Limitations and Difficulties," International Conference on Dubbing and Subtitling in a World Context (19.10.2001), Translation Department, Chinese University of Hong Kong. Hong Kong, 
Syun, L. (1995): Mei Tyunnaai dik Manzuk [The Unweaned Race], Taipei, Geoilau Tousyu.

Syun, L. (1992): Zunggwok Manfaa dik Samcang Gitkau [The Deep Structure of Chinese Culture], Hong Kong, Zaapjin Se.

Hoenggong Jyujinhok Hokwui (Linguistic Society of Hong Kong) (1997): Jyutjyu Pingjam Zibiu [A Glossary of Cantonese Romanization], Hong Kong: Linguistic Society of Hong Kong.

ZAu, W. and M. ZIU (1995): Jigwai Singsi [A Sexual History of Closets]. Hong Kong, Hoenggong Tungzi Jingau Se.

$V C D$

Castellaneta, P. J. (1998): Relax... It's Just Sex, performance Jennifer Tilly and Mitchell Anderson, Asian Video Publishing Co., Ltd.

Demme, J. (2001): Silence of the Lamb, perf. Jodie Foster and Anthony Hopkins, Deltamac (Hong Kong) Co. Ltd.

Harron, M. (2000): American Psycho, perf. Christian Bale, Willem Defoe, and Jared Leto, Intercontinental Video Limited.

Mendes, S. (1999): American Beauty, perf. Kevin Spacey and Annette Benning, Cic Home Entertainment (Hong Kong) Company Limited.

Sмiтн, K. (1999): Dogma, perf. Matt Damon and Ben Affleck, Era Home Entertainment Ltd.

Tarantino, Q. (1994): Pulp Fiction, perf. John Travolta, Bruce Willis, and Uma Thurman, Intercontinental Video Limited.

Wayans, K. I. (2000): Scary Movie, perf. Shannon Elizabeth, Anna Faris, and Shawn Wayans, Era Films (HK) Limited. 
論文作者簡介

曾焯文, 英文榮譽學士, 翻譯碩士, 文學博士。曾專業口譯與筆譯多年, 現任香港理工大 學中文及雙語學系助理教授, 並爲香港翻譯學會會員、香港心理治療學會會員。著有《達 夫心經》(香港 : 香江出版社, 1999)、《《洛麗桃》與《圓舞》: 兩本兒童情慾小說〉(2000)、 〈近親戀日記的情色翻譯〉(2000)等。

\section{APPENDIX}

A Subtitling Table of Swearwords

\begin{tabular}{|c|c|c|c|}
\hline \begin{tabular}{|l|} 
English \\
Original
\end{tabular} & VCD Subtitled Version & $\begin{array}{l}\text { The Writer's Suggestion for } \\
\text { Category III and Category IIB } \\
\text { movies }\end{array}$ & $\begin{array}{l}\text { Sugges- } \\
\text { tion for } \\
\text { Category IIA } \\
\& I^{1} \text { Movies }\end{array}$ \\
\hline asshole & $\begin{array}{l}\text { Wan-daan 混蛋 [wretch] } \\
\text { Wong-baat-daan 王八蛋 } \\
\text { [shameless guy] }\end{array}$ & $\begin{array}{l}\text { si-fat gwai 屎忽鬼[ass ghost] } \\
\text { /caap-nei si-fat 插你屎忽 [poke } \\
\text { your ass] } \\
\text { so-po, nei hai-dou tung go } \\
\text { si-fat-gwai paak-to 俊婆, 你係度 } \\
\text { 同個屎忽鬼拍拖 [Stupid woman, } \\
\text { you're dating an asshole] }\end{array}$ & $\begin{array}{l}\text { si-fat gwai 屎 } \\
\text { 忽鬼 }\end{array}$ \\
\hline cock/dick/prick & $\begin{array}{l}\text { Tiu-je 條 } \square \text { [the strip of thing] } \\
\text { joeng-geoi 陽具[penis] } \\
\text { E.g. } 1 \text { Dude, his dick is gonna } \\
\text { be rubbing all over the inside of }\end{array}$ & $\begin{array}{l}\text { lan / luk-je 碌 [strip of thing] } \\
\text { fan-coeng 粉腸 [rice roll] } \\
\text { gau [cock] }\end{array}$ & $\begin{array}{l}\text { fan-coeng 粉 } \\
\text { 腸/ } \\
\text { luk-je 碌 / } \\
\text { sai-lou 細佬/ } \\
\text { ho-bi-zai 何 B }\end{array}$ \\
\hline
\end{tabular}




\begin{tabular}{|c|c|c|c|}
\hline & $\begin{array}{l}\text { your armor! } \\
\text { Tiu-je hai-gam haai-lok gin pei } \\
\text { dou 條口係咁揩落件披度 [The } \\
\text { strip keeps rubbing over your } \\
\text { coat] (Dogma [1999] [Category } \\
\text { IIB]) } \\
\text { E.g. 2. You're right. I suck dick } \\
\text { for money. } \\
\text { Nei caai deoi liu, ngo bong-jan } \\
\text { hau-gaau zaan-cin 你猜對了 } \\
\text { 我幫人口交賺錢 [You guess } \\
\text { rightly, I perform oral sex for } \\
\text { others to earn } \\
\text { money.](American Beauty } \\
\text { [2000] [Category III]) } \\
\text { E.g. 3. Stop sticking your dick } \\
\text { in the vacuum cleaner. } \\
\text { Bit baa joeng-geoi fong-zeoi } \\
\text { kap-can-gei 別把陽具放進吸 } \\
\text { 塵機 [Don't put your penis into } \\
\text { the vacuum cleaner] (Scary } \\
\text { Movie) }\end{array}$ & $\begin{array}{l}\text { Lok-je hai-gam haai-lok gin pei } \\
\text { dou 碌 係咁揩落件披度 [The } \\
\text { strip keeps rubbing over your } \\
\text { coat] } \\
\text { Nei gu-ngaam zo, ngo bong jan } \\
\text { ham-lan zaan-cin 你估, 我 } \\
\text { 幫人含 賺錢 [You guess rightly, } \\
\text { I suck people's cock for money] } \\
\text { Mai fong luk-je jap kap-can-gei 咪 } \\
\text { 放碌 入吸鹿機 [Don't put your } \\
\text { roll of thing into the vacuum } \\
\text { cleaner] }\end{array}$ & 仔 \\
\hline cock-sucker & $\begin{array}{l}\text { I will not sit back and watch my } \\
\text { only son become a cocksucker! } \\
\text { Ji-zi bin-sing gei-lou, ngo bat- } \\
\text { Wui zau-sau bong-gun dik 兒子 } \\
\text { 變成基佬, 我不會袖手旁觀的 } \\
\text { [My son is becoming a gay guy, } \\
\text { I won't sit back and watch] } \\
\text { (American Beauty [2000] } \\
\text { [Category III]) }\end{array}$ & $\begin{array}{l}\text { ham-lan 含 [suck the prick] } \\
\text { ngo m-wui tai-zyu go- } \\
\text { zai tung-jan ham-lan m-lei ge 我 } \\
\text { 唔會睇住個仔同人含 唔理 } \\
\text { won't watch my son sucking dick } \\
\text { for other people without doing } \\
\text { anything.] }\end{array}$ & $\begin{array}{l}\text { Jaak-ziu 喫蕉 } \\
\text { [eat banana] }\end{array}$ \\
\hline cunt & $\begin{array}{l}\text { jam-bou 陰部 [genitalia] } \\
\text { /haa-tai 下體 [lower part of the } \\
\text { body] } \\
\text { E.g. I can smell your cunt } \\
\text { Ngo men-dou nei-dik jam-bou } \\
\text { 我聞到你的陰部[I smell your } \\
\text { genitalia] (Silence of the Lambs } \\
\text { [1991] [Category III]) }\end{array}$ & $\begin{array}{l}\text { hai [cunt] } \\
\text { Ngo men-dou nei-ge cau-hai 我聞 } \\
\text { 到你 臭 [I can smell your } \\
\text { stinking cunt] }\end{array}$ & $\begin{array}{l}\text { jam-bou 陰部 } \\
\text { /haa-tai 下體 } \\
\text { /sai } \\
\text { 西 [West] }\end{array}$ \\
\hline faggot & gei-lou 死基佬 [Dead gay guy] & sei gei-lou 死基佬/kai-dai 契弟 & sei-gei-lou 死 \\
\hline
\end{tabular}




\begin{tabular}{|c|c|c|c|}
\hline & $\begin{array}{l}\text { E.g. I'd rather you were dead } \\
\text { than be a fucking faggot. } \\
\text { Ngo ning-jyun nei sei-zo jaa } \\
\text { bat-soeng nei si gei-lou 我寧願 } \\
\text { 你死 也不想你是基佬 [I } \\
\text { would rather you were dead } \\
\text { than be a gay guy ] } \\
\text { (American Beauty) }\end{array}$ & $\mid \begin{array}{l}\text { [feminine younger brother] } \\
\text { ngo ning-jyun nei sei-lan--zo dou } \\
\text { hou-gwo nei zou gei-lou 我寧願你 } \\
\text { 死 都好過你做基佬[ [ I would } \\
\text { rather you were prick dead than be } \\
\text { a gay guy] }\end{array}$ & \begin{tabular}{|l} 
基佬/kai-dai \\
契弟
\end{tabular} \\
\hline fuck (vb.) & $\begin{array}{l}\text { cou 操 [drill]; heoi nei-dik 去你 } \\
\text { 的 [off yours] } \\
\text { E.g. } 1 \text { I just have fucked him for } \\
\text { a couple of times. } \\
\text { Ngo zi-bat-gwo cou-gwo taa } \\
\text { jat-loeng ci } \\
\text { 我只不過操過他一兩次 [I just } \\
\text { have drilled him once or twice] } \\
\text { (Scary Movie [2000] [Category } \\
\text { IIB]) } \\
\text { E.g. 2. I don't need any drink. } \\
\text { Fuck you. } \\
\text { Ngo bat-jiu. Heoi nei-dik. } \\
\text { 我不要. 去你的. [I don't want } \\
\text { it. Off yours.] (There is } \\
\text { Something about Mary [1998] } \\
\text { [Category IIB]) }\end{array}$ & $\begin{array}{l}\text { diu [fuck] } \\
\text { Ngo zing-hai diu-gwo koei jat } \\
\text { loeng ci 我淨係 過佢一兩次 [I } \\
\text { have only fucked him once or } \\
\text { twice] }\end{array}$ & siu 小 \\
\hline fuck (n.) & $\begin{array}{l}\text { Jiu 妖[freak]/taa-maa-dik } \\
\text { 他媽的[his mother's \{cunt\}]/ } \\
\text { untranslated } \\
\text { E.g. Exactly, what the fuck is } \\
\text { this? } \\
\text { Jiu! Syut-dak hou! Ze-si } \\
\text { sam-mou jiu dung-sai? } \\
\text { 妖! 說得好! 這是甚麼妖東西? } \\
{[\text { [Jiu \{freak\}, good, what is this }} \\
\text { jiu thing?] (Relax...It's Just Sex } \\
{[1998] \text { [Category III]) }}\end{array}$ & 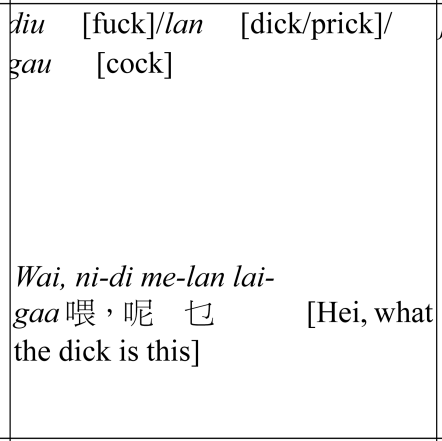 & jiu 妖 [freak] \\
\hline fucking & $\begin{array}{l}\text { Taa-maa-dik 他媽的 } \\
\text { [his mother's] } \\
\text { E.g. 1. I fucking hate you } \\
\text { Ngo taa-maa-dik han nei 我他 } \\
\text { 媽的恨你 [I his mother's hate }\end{array}$ & $\begin{array}{l}\text { lan }[\text { prick/dick]/gau [cock] } \\
\text { ngo zang-lan sei nei 我憎 死你 } \\
{\left[\begin{array}{l}\text { I hate prick you }]\end{array}\right.}\end{array}$ & $\begin{array}{l}\text { Q/gaau 膠 } \\
\text { [plastic] }\end{array}$ \\
\hline
\end{tabular}




\begin{tabular}{|c|c|c|c|}
\hline & \begin{tabular}{|l|} 
you] (Dogma [1999] [Category \\
IIB]) \\
E.g. 2. I chopped his fucking \\
head off \\
Ngo baa ngaai-leon dik tau \\
zaam-liu haa-loi liu 我把艾倫 \\
的頭斬了下來了 [I chopped off \\
Allen's head] (American Psycho \\
[2000] [Category III])
\end{tabular} & $\begin{array}{l}\text { ngo zaam-lan zo koei ge tau 我斬 } \\
\text { 佢 頭 [I chopped prick off } \\
\text { his head] }\end{array}$ & \\
\hline Goddamn/damn & $\begin{array}{l}\text { maa-dik 媽的 [mother's] } \\
\text { /untranslated } \\
\text { E.g. 1. Get a Goddamn job } \\
\text { Heoi zau jat-fan gung maa, } \\
\text { maa-dik 去找一份工嘛, 媽的 } \\
\text { [Go find a job, mother's] } \\
\text { (American Psycho) } \\
\\
\text { E.g. 2. I dare ya, I double } \\
\text { dare ya mother-fucker, say } \\
\text { "What" one more goddamn } \\
\text { time! } \\
\text { Nei jau-zung zau syut do jat-ci } \\
\text { "sam-mo”你有種便說多一次 } \\
\text { “甚麼” [If you have seeds, then } \\
\text { say “What” one more time] } \\
\text { (Pulp Fiction) }\end{array}$ & $\begin{array}{l}\text { ding 頂 [butt] /sei 死 [dead]/lan } \\
\text { /diunei [fuck you] } \\
\text { heoi wan-gung la, diunei 去搵工 } \\
\text { 啦, 你[Oh, Go find a job, fuck } \\
\text { you] } \\
\\
\text { diu-nei lou-mou, gau daam zau } \\
\text { gong do-ci me-waa 你老母, 夠 } \\
\text { 膽就講 多次也話[fuck your } \\
\text { mother, if you have guts, say prick } \\
\text { “What” one more time] }\end{array}$ & ding 頂/sei 死 \\
\hline \multirow[t]{2}{*}{ mother-fucker } & $\begin{array}{l}\text { E.g. 1. Who is this mother- } \\
\text { fucker? } \\
\text { Ze-go puk-gaai si seoi } \\
\text { 這個仆街是誰 [Who is this } \\
\text { drop-dead-in-the-street] } \\
\text { (Dogma [1999] [Category IIB]) }\end{array}$ & $\begin{array}{l}\text { diu-nei lou-mou 你老母 } \\
\text { /ham-gaa-caan 家產] } \\
\text { [whole-family-uprooted]/puk-gaai } \\
\text { 仆街 [drop-dead-in-the-street/ } \\
\text { laan-taan 躝瘼保 [paralytic] } \\
\\
\text { ni-tiu puk-ggai hai bing-go 呢條 } \\
\text { 仆街係邊個 [Who is this strip of } \\
\text { drop-dead-in-the-street] }\end{array}$ & $\begin{array}{l}\text { puk-gaa 仆街 } \\
\text { sei-zai } \\
i \text { 死仔 }\end{array}$ \\
\hline & $\begin{array}{l}\text { English-motherfucker-can-you } \\
\text {-speak-it? } \\
\text { jing-jyu, waai-zung, nei dung } \\
\text { syut ma 英語, 艰種, 你懂說 }\end{array}$ & 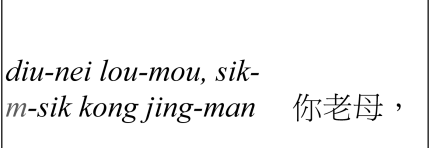 & \\
\hline
\end{tabular}




\begin{tabular}{|c|c|c|c|}
\hline & \begin{tabular}{|l} 
嗎? [English, bad seed, do you \\
know how to speak] (Pulp \\
Fiction [1994] [Category III]) \\
E.g. 3. Any of you fuckin' \\
pricks move \\
Joek jau jan lyun-dung 若有人 \\
亂動...[Should anybody move \\
randomly...] \\
and I'll execute every last one of \\
you mother-fuckers! Got that? \\
ngo wui jat-jat saat-sei nei-mun \\
我會一一殺死你們[I will kill \\
you all]
\end{tabular} & 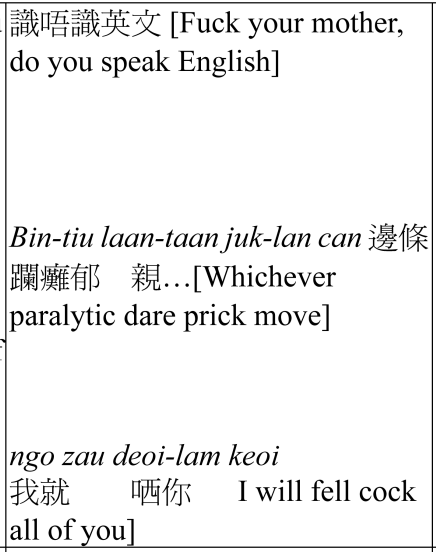 & \\
\hline shit & $\begin{array}{l}\text { Untranslated/zou-gou 糟糕 [Oh } \\
\text { no/what bad luck] } \\
\text { In Scary Movie, “Oh Shit!" } \\
\text { appears many times but remains } \\
\text { untranslated }\end{array}$ & $\begin{array}{l}\text { sik-si 食屎[eat shit] /ding 頂 } \\
\text { [butt]/daai-lan-wok大 鎨 [big } \\
\text { prick cauldron] }\end{array}$ & $\begin{array}{l}\text { sik-si 食屎 } \\
/ \text { ding 頂 [butt]/ } \\
\text { daai-wok } \\
\text { 大鑊[big } \\
\text { cauldron] }\end{array}$ \\
\hline
\end{tabular}

